Check for updates

Cite this: RSC Adv., 2018, 8, 4348

Received 14th December 2017 Accepted 14th January 2018

DOI: $10.1039 / \mathrm{c} 7 \mathrm{ra13327h}$

rsc.li/rsc-advances

\section{Penicilazaphilones D and E: two new azaphilones from a sponge-derived strain of the fungus Penicillium sclerotiorum $\uparrow$}

\author{
Chao-Yi Wang, ${ }^{\text {ab }}$ Jun-Di Hao, ${ }^{\text {ab }}$ Xing-Yan Ning, ${ }^{\text {ab }}$ Jing-Shuai Wu, ${ }^{\text {ab }}$ Dong-Lin Zhao, ${ }^{\text {ab }}$ \\ Chui-Jian Kong, ${ }^{\text {ab }}$ Chang-Lun Shao*ab and Chang-Yun Wang ${ }^{*}$ *abc
}

Two new azaphilones, penicilazaphilones D (1) and E (2), along with four known analogs (3-6), were obtained from the sponge-derived fungus Penicillium sclerotiorum. Their structures were elucidated on the basis of comprehensive spectroscopic analyses, ECD calculation, single-crystal X-ray diffraction and comparison to the biosynthetically related compound 5. Compound 1 represents the second reported azaphilone with a C-4 aliphatic side chain, and 2 is the first azaphilone with a tetrahydrofuran ring at C-3. Compound 3 displayed strong antiviral activity against HSV $\left(\mathrm{IC}_{50}=19.5 \mu \mathrm{M}\right)$ and $\mathrm{EV71}\left(\mathrm{IC}_{50}=\right.$ $132 \mu \mathrm{M}), 16$ and 3 fold more potent than the positive control ribavirin, respectively.

\section{Introduction}

Marine-derived fungi represent a huge potential for new natural products, which often show pharmaceutically relevant bioactivities. ${ }^{\mathbf{1}, 2}$ The genus Penicillium, which received great attention among all marine-derived fungi, is becoming a promising reservoir of marine natural products with novel structures and potential bioactivities. ${ }^{2,3}$ It was reported that sponges are the main hosts of marine symbiotic Penicillium sp. fungi for producing new marine natural products. ${ }^{3}$ Specifically, a growing number of azaphilone derivatives have been reported from the marine-derived fungi including Penicillium with various biologic activities, such as cytotoxic, antibacterial, antifungal, and enzyme inhibitory activities. ${ }^{4-8}$

In the course of our ongoing investigation on new bioactive secondary metabolites from the genus Penicillium in the South China Sea, ${ }^{9-14}$ a sponge-derived fungal strain, P. sclerotiorum GDST-2013-0415, attracted our attention, because the extract of the fungal culture showed antibacterial activity. Chemical investigation of the EtOAc crude extract led to the isolation of

${ }^{a}$ Key Laboratory of Marine Drugs, The Ministry of Education of China, School of Medicine and Pharmacy, Ocean University of China, Qingdao 266003, People's Republic of China. E-mail: changyun@ouc.edu.cn; shaochanglun@ouc.edu.cn; Tel: +86-532-8203-1536; +86-532-8203-1381

${ }^{b}$ Laboratory for Marine Drugs and Bioproducts, Qingdao National Laboratory for Marine Science and Technology, Qingdao 266003, People's Republic of China

'Institute of Evolution \& Marine Biodiversity, Ocean University of China, Qingdao 266003, People's Republic of China

$\dagger$ Electronic supplementary information (ESI) available: ESIMS, HRESIMS, 1D, 2D NMR data of compounds 1 and 2; ECD calculation details of 1 ; ${ }^{1} \mathrm{H}$ and ${ }^{13} \mathrm{C}$ NMR data for 5; antibacterial activities of 3 against bacterial strains. CCDC 1445322 and 1445327. For ESI and crystallographic data in CIF or other electronic format see DOI: $10.1039 / \mathrm{c} 7 \mathrm{ra} 13327 \mathrm{~h}$ two new azaphilone derivatives, penicilazaphilones D and E (1 and 2), together with four known compounds (+)-sclerotiorin (3), ${ }^{15}$ geumsanol C (4), ${ }^{16}$ WB (CAS no. 1701443-52-8, 6H-2benzopyran-6-one, 5-chloro-3-[(1E,3R,4R,5S)-3,4-dihydroxy-3,5dimethyl-1-hepten-1-yl]-1,7,8,8a-tetrahydro-7,8-dihydroxy-7-methyl$(7 R, 8 R, 8 \mathrm{a} S))(5)^{17,18}$ and geumsanol $\mathrm{G}(\mathbf{6}){ }^{16}$ The structures of compounds 1-6 were established on the basis of spectroscopic analysis, and the absolute configurations of $\mathbf{1}$ and $\mathbf{6}$ were determined by single-crystal X-ray diffraction analysis. Herein we report the isolation, structure elucidation, and biological activities of these compounds.

\section{Results and discussion}

The sponge-derived fungal strain, Penicillium sclertiorum GDST2013-0415, was cultured with rice medium in fifty Erlenmeyer flasks at room temperature for 40 days. The fermented rice medium was extracted three times with EtOAc. The combined EtOAc layers were evaporated under reduced pressure to give the EtOAc extract $(65 \mathrm{~g})$. By repeated column chromatography (CC) over silica gel, octadecylsilyl (ODS), Sephadex LH-20, and

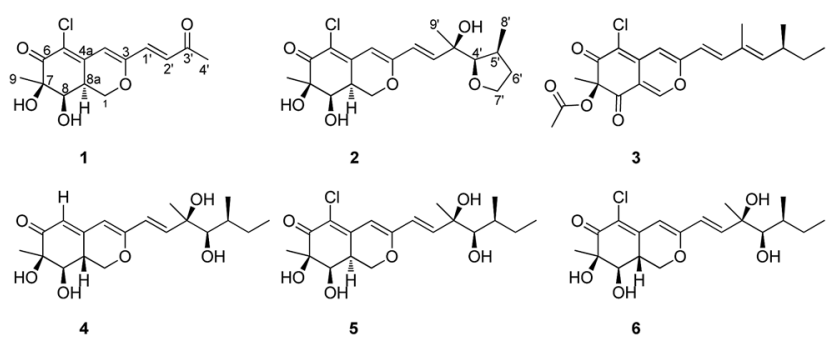

Fig. 1 The structures of compounds 1-6. 
semi-preparative HPLC, six compounds, 1-6, were obtained (Fig. 1).

Penicilazaphilone $\mathrm{D}(\mathbf{1})$ was isolated as a yellow gum with the molecular formula of $\mathrm{C}_{14} \mathrm{H}_{15} \mathrm{ClO}_{5}$ based on HRESIMS, for which seven degrees of unsaturation were required. The IR spectrum of 1 exhibited the presence of hydroxyl $\left(3633 \mathrm{~cm}^{-1}\right)$, and conjugated carbonyl $\left(1701 \mathrm{~cm}^{-1}\right)$ groups. The ${ }^{1} \mathrm{H}$ NMR spectroscopic data (Table 1) exhibited signals for three olefinic protons at $\delta_{\mathrm{H}} 7.20(\mathrm{~d}, J=15.9 \mathrm{~Hz}), 6.61(\mathrm{~d}, J=15.9 \mathrm{~Hz})$ and 6.50 (s), two methyl groups at $\delta_{\mathrm{H}} 2.33(\mathrm{~s})$ and $1.35(\mathrm{~s})$, two methine protons at $\delta_{\mathrm{H}} 4.18(\mathrm{~d}, J=3.1 \mathrm{~Hz})$ and $3.29(\mathrm{~m})$, and one methylene group at $\delta_{\mathrm{H}} 4.66(\mathrm{dd}, J=11.0,4.9 \mathrm{~Hz})$ and $4.21(\mathrm{dd}, J=$ 13.0, $11.0 \mathrm{~Hz}$ ). The ${ }^{13} \mathrm{C}$ NMR spectroscopic data (Table 1) showed eight $\mathrm{sp}^{2}$-hybridized carbons in 1 , including two carbonyl carbons at $\delta_{\mathrm{C}} 197.9$ and 194.5 , six olefinic carbons at $\delta_{\mathrm{C}}$ $159.5,143.7,136.1,131.5,120.5$ and 108.7, and six sp ${ }^{3}$-hybridized carbons including two methyl groups at $\delta_{\mathrm{C}} 27.7$ and 23.4, two methine groups at $\delta_{\mathrm{C}} 75.1$ and 37.9, one methylene group at $\delta_{\mathrm{C}} 69.5$, and one quaternary carbon at $\delta_{\mathrm{C}}$ 79.0. These spectroscopic features suggested that $\mathbf{1}$ shares the same bicyclic core of azaphilone as WB (CAS no. 1701443-52-8) (5), an azaphilone derivative isolated from a soil fungus and determined only the plane structure, ${ }^{17}$ then from an entomopathogenic fungus Hypocrella sp. reported the absolute configuration. ${ }^{18}$ The main differences were the presence of a 3-buten-2-one group [ $[-\mathrm{CH}=$ $\left.\mathrm{CHC}(\mathrm{O}) \mathrm{CH}_{3}\right]$ at $\mathrm{C}-3$ in 1 instead of the $\left[-\mathrm{CH}=\mathrm{CHCOH}\left(\mathrm{CH}_{3}\right)\right.$ $\left.\mathrm{CH}(\mathrm{OH}) \mathrm{CH}\left(\mathrm{CH}_{3}\right) \mathrm{CH}_{2} \mathrm{CH}_{3}\right]$ fragment in 5 , which was confirmed by the COSY cross-peaks and HMBC correlations (Fig. 2). In the ${ }^{1} \mathrm{H}-{ }^{1} \mathrm{H}$ COSY spectrum, the cross peak of $\mathrm{H}-1^{\prime} / \mathrm{H}-2^{\prime}$, together with $\mathrm{HMBC}$ correlations from $\mathrm{H}-1^{\prime}$ to $\mathrm{C}-4$ and $\mathrm{C}-3^{\prime}$, from $\mathrm{H}-2^{\prime}$ to $\mathrm{C}-3$, and from $\mathrm{H}-4^{\prime}$ to $\mathrm{C}-2^{\prime}$ established a 3-buten-2-one unit

Table $1{ }^{1} \mathrm{H}(500 \mathrm{MHz})$ and ${ }^{13} \mathrm{C}(125 \mathrm{MHz})$ NMR Data for 1 and 2

\begin{tabular}{|c|c|c|c|c|}
\hline \multirow[b]{2}{*}{ No. } & \multicolumn{2}{|l|}{1} & \multicolumn{2}{|l|}{2} \\
\hline & $\delta_{\mathrm{C}}^{a}$, type & $\delta_{\mathrm{H}}^{a}(J$ in $\mathrm{Hz})$ & $\delta_{\mathrm{C}}{ }^{a}$, type & $\delta_{\mathrm{H}}^{a}(J$ in $\mathrm{Hz})$ \\
\hline \multirow[t]{2}{*}{1} & \multirow[t]{2}{*}{$69.5, \mathrm{CH}_{2}$} & $4.21, \mathrm{dd}(13.0,11.0)$ & \multirow[t]{2}{*}{$69.3, \mathrm{CH}_{2}$} & 4.25, dd $(13.2,11.0)^{b}$ \\
\hline & & $4.66, \mathrm{dd}(11.0,4.9)$ & & 4.60, dd $(11.0,4.9)$ \\
\hline 3 & 159.5, C & & $162.5, \mathrm{C}$ & \\
\hline 4 & $108.7, \mathrm{CH}$ & $6.50, \mathrm{~s}$ & 102.1, CH & $6.06, \mathrm{~s}$ \\
\hline $4 a$ & 143.7, C & & $145.6, \mathrm{C}$ & \\
\hline 5 & $120.5, \mathrm{C}$ & & 117.1, C & \\
\hline 6 & 194.5, C & & 193.9, C & \\
\hline 7 & $79.0, \mathrm{C}$ & & 78.6, C & \\
\hline 8 & 75.1, $\mathrm{CH}$ & $4.18, \mathrm{~d}(3.1)$ & $75.1, \mathrm{CH}$ & $4.12, \mathrm{~d}(3.0)^{b}$ \\
\hline $8 \mathrm{a}$ & $37.9, \mathrm{CH}$ & $3.29, \mathrm{~m}$ & $38.0, \mathrm{CH}$ & $3.22, \mathrm{~m}$ \\
\hline 9 & $23.4, \mathrm{CH}_{3}$ & $1.35, \mathrm{~s}$ & 26.5, $\mathrm{CH}_{3}$ & $1.340, \mathrm{~s}$ \\
\hline $1^{\prime}$ & 136.1, $\mathrm{CH}$ & $7.20, \mathrm{~d}(15.9)$ & 122.2, $\mathrm{CH}$ & 6.36, d (15.5) \\
\hline $2^{\prime}$ & $131.5, \mathrm{CH}$ & 6.61, d (15.9) & 145.6, CH & $6.77, d(15.5)$ \\
\hline $3^{\prime}$ & 197.9, C & & $76.2, \mathrm{C}$ & \\
\hline $4^{\prime}$ & $27.7, \mathrm{CH}_{3}$ & $2.33, \mathrm{~s}$ & $80.5, \mathrm{CH}$ & $3.52, \mathrm{~d}(2.0)$ \\
\hline $5^{\prime}$ & & & $31.2, \mathrm{CH}$ & $2.10, \mathrm{~m}$ \\
\hline $6^{\prime}$ & & & $40.0, \mathrm{CH}_{2}$ & $1.66, \mathrm{~m}$ \\
\hline & & & & $1.53, \mathrm{~m}$ \\
\hline $7^{\prime}$ & & & $60.1, \mathrm{CH}_{2}$ & $3.60, \mathrm{~m}$ \\
\hline $8^{\prime}$ & & & $14.2, \mathrm{CH}_{3}$ & $0.91, \mathrm{~d}(6.9)$ \\
\hline $9^{\prime}$ & & & $23.7, \mathrm{CH}_{3}$ & $1.336, \mathrm{~s}$ \\
\hline
\end{tabular}

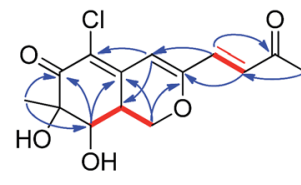

1

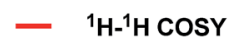

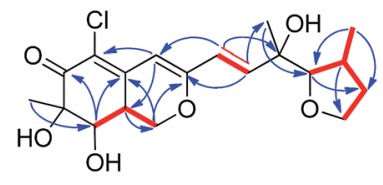

2
Fig. $2{ }^{1} \mathrm{H}-{ }^{1} \mathrm{H}$ COSY and key HMBC correlations of compounds 1 and 2.

linked with C-3. The relative configuration of $\mathbf{1}$ was determined by ${ }^{1} \mathrm{H}^{-1} \mathrm{H}$ coupling constants and NOESY correlations. The cisrelationship of $\mathrm{H}-8 / \mathrm{H}-8 \mathrm{a}$ was deduced from the eq/ax coupling constant $\left(J_{8,8 \mathrm{a}}=3.1 \mathrm{~Hz}\right.$ ). In the NOESY spectrum (Fig. 3), NOESY correlations were observed between $\mathrm{H}_{3}-9$ and $\mathrm{H}-8$, indicating the cofacial orientation relative to these protons. On the basis of these results, the complete planar assignment for compound $\mathbf{1}$ was established.

The absolute configuration of $\mathbf{1}$ was determined by comparing the theoretical calculation ECD with the experimental ECD. Conformational searches were carried out using Merck Molecular Force Field (MMFF) by means of the Spartan's 10 software to acquire meaningful conformers for $7 R, 8 R, 8 \mathrm{a} S-\mathbf{1}$, followed by DFT optimizations at the B3LYP/6-31+G(d,p) level in MeOH by CPCM polarizable conductor calculation model. The ECD spectrum was calculated by the TDDFT methodology with a larger basis set at the B3LYP/6-311+G(d,p) level and generated using SpecDis 1.6 according to Boltzmann distributions. The theoretical ECD spectrum for $7 S, 8 S, 8 \mathrm{a} R-1$ was obtained by directly reversing the spectrum of $7 R, 8 R, 8 \mathrm{a} S-\mathbf{1}$. For compound $\mathbf{1}$ the experimental positive Cotton effect at $250 \mathrm{~nm}(\Delta \varepsilon+14.32)$, and negative Cotton effects at $218 \mathrm{~nm}(\Delta \varepsilon-6.14)$ and $328 \mathrm{~nm}$ $(\Delta \varepsilon-3.83)$ compared well with the calculated ECD curve for $7 R, 8 R, 8 \mathrm{a} S-1$, which showed three corresponding Cotton effects around $257 \mathrm{~nm}(\Delta \varepsilon+15.21), 223 \mathrm{~nm}(\Delta \varepsilon-17.65)$, and $325 \mathrm{~nm}$ $(\Delta \varepsilon-2.90)$, respectively (Fig. 4$)$. Therefore, qualitative analysis of the results allowed the assignment of the absolute configuration of $\mathbf{1}$ as $7 R, 8 R, 8 \mathrm{a} S$.

To confirm the absolute configuration, we undertook a single X-ray diffraction study. Ultimately, by slow crystallization from the mixture of $\mathrm{CH}_{2} \mathrm{Cl}_{2}$ and $\mathrm{CH}_{3} \mathrm{OH}$, single crystals of 1 suitable for X-ray diffraction were obtained. The Mo K $\alpha$ radiation used for the X-ray diffraction allowed the assignment of the absolute configuration of all of the stereogenic centers in $\mathbf{1}$, which contains heavy atom chlorine, as $7 R, 8 R$ and 8 aS through refinement of Flack's parameter $-0.07(3)$ (Fig. 5).

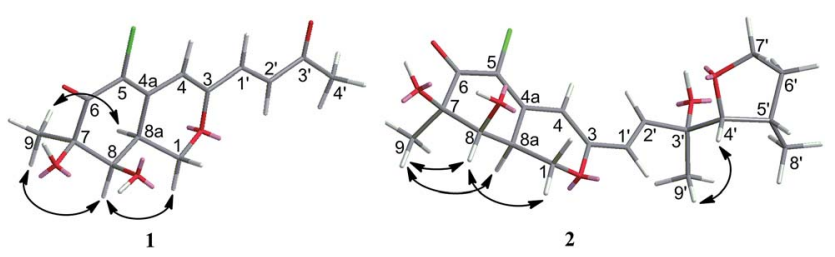

Fig. 3 Selected NOESY correlations of 1 and 2 . 


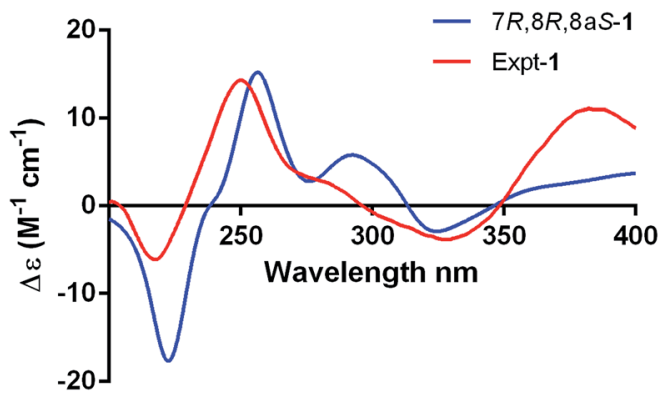

Fig. 4 Experimental and calculated ECD spectra for $7 R, 8 R, 8 \mathrm{a} S-1$.

Penicilazaphilone E (2) was also obtained as a yellow gum, possessing a molecular formula of $\mathrm{C}_{19} \mathrm{H}_{25} \mathrm{ClO}_{6}$ with seven degrees of unsaturation. The IR spectrum indicated the presence of hydroxyl $\left(3752 \mathrm{~cm}^{-1}\right)$ and conjugated carbonyl $\left(1703 \mathrm{~cm}^{-1}\right.$ ) groups. The ${ }^{13} \mathrm{C}$ NMR spectroscopic data (Table 1) displayed the presence of 19 carbon signals including one carbonyl carbon $\left(\delta_{\mathrm{C}} 193.9\right)$ and six olefinic carbons, three methyl groups, three methylene groups, four methine groups, and two quaternary carbons. In the ${ }^{1} \mathrm{H}$ NMR spectrum, three olefinic protons at $\delta_{\mathrm{H}} 6.77(\mathrm{~d}, J=15.5 \mathrm{~Hz}), 6.36(\mathrm{~d}, J=15.5 \mathrm{~Hz})$ and $6.06(\mathrm{~s})$, three methyl groups, three methylene groups, and four methine groups were observed. Detailed analysis of the ${ }^{1} \mathrm{H}$ and ${ }^{13} \mathrm{C}$ NMR spectroscopic data (Table 1) revealed that 2 is an azaphilone derivative, also closely related to WB (CAS no. 1701443-52-8) (5). ${ }^{17,18}$ Comparision of the ${ }^{1} \mathrm{H}$ and ${ }^{13} \mathrm{C}$ NMR data revealed that 2 differed from 5 only at the side chains. The terminal methyl of the side chain at $\delta_{\mathrm{H}} 0.91, \delta_{\mathrm{C}} 11.8$ in 5 were absent in 2. Instead, the signals for a methylene at $\delta_{\mathrm{H}} 3.60, \delta_{\mathrm{C}}$ 60.1 were observed in 2 . Furthermore, the above structural moiety accounts for six unsaturation degrees (one carbonyl, six olefinic carbons, and the bicyclic core of azaphilone), indicated that 2 must contain another ring. The contiguous sequence of correlations from $\mathrm{H}-4^{\prime}$ to $\mathrm{H}-7^{\prime}$ in the COSY spectrum and the HMBC correlations from $\mathrm{H}-5^{\prime}$ to $\mathrm{C}-7^{\prime}$ and $\mathrm{H}-4^{\prime}$ to $\mathrm{C}-6^{\prime}$ indicated the presence of a tetrahydrofuran ring (Fig. 2).

The relative configuration of 2 was determined also by ${ }^{1} \mathrm{H}-{ }^{1} \mathrm{H}$ coupling constants and NOESY data revealing a bicyclic core with the same relative configurations as $\mathbf{1}$ and $\mathbf{5}$ (Fig. 3). Specifically, the cis-relationship of $\mathrm{H}-4^{\prime} / \mathrm{H}-5^{\prime}$ in the side chain was deduced from the coupling constant $\left(J_{4^{\prime}}, 5^{\prime}=2.0 \mathrm{~Hz}\right)$. The NOESY correlations of $\mathrm{H}_{3}-9^{\prime} / \mathrm{H}-4^{\prime}$ indicated that these protons located on the same side of the moiety. Thus, the relative configurations of 2 were determined. The absolute configuration of 2 could not be assigned only by ECD method, while the

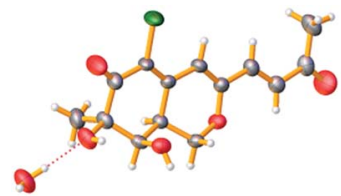

1

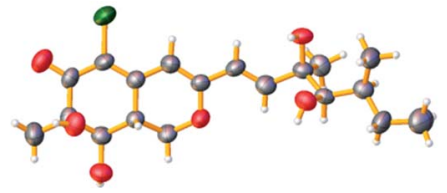

6
Fig. 5 Single-crystal X-ray structures of compounds 1 and 6 absolute configuration of the side chain in 2 could not be determined by Mosher's method as 5 (ref. 18) because of the presence of tetrahydrofuran ring in the side chain. Unfortunately, the cultivation of single crystal of 2 was failed, even cultivated by the 4 -bromobenzoate derivative of 2 . And due to the limitation of compound amount, the absolute configuration of 2 was tentatively determined by biosynthetic pathways. Compound 2 was proposed to be a cyclized form of 5 between $7^{\prime}$ methyl and $4^{\prime}-\mathrm{OH}$, that is, 5 was the precursor of 2 . The plausible biosynthetic pathways from 5 to 2 were proposed. As depicted in Scheme 1, 5 is initially oxidized at side-chain by a cytochrome $\mathbf{P} 450$ hydroxylase to form a C-terminal hydroxylated product (a). Then the intermediate (a) undergoes a cyclic reaction between $7^{\prime}$-methyl and $4^{\prime}-\mathrm{OH}$. It appears conceivable that a have two different cyclization pathways. Path 1: the dehydration of $7^{\prime}-\mathrm{OH}$ leads to the nucleophilic attack from $4^{\prime}-\mathrm{O}^{-}$ to $7^{\prime}-\mathrm{C}^{+}$, which directly gives 2 . Path 2 : the dehydration of $4^{\prime}-\mathrm{OH}$ result in the nucleophilic attack from $7^{\prime}-\mathrm{O}^{-}$to $4^{\prime}-\mathrm{C}^{+}$, which could yield two possible products, $\mathbf{2}$ and $\mathbf{b}$, on account of the rotation of the side chain. Owing to the fact that the relative configuration of $\mathbf{2}$ is identical with that of $\mathbf{5}$, the absolute configuration of 2 was proposed to be identical to that of the precursor 5 tentatively.

Azaphilones are a class of structurally variable fungal polyketide metabolites isolated mainly from the ascomyceteous fungi, such as genera Penicillium, Aspergillus, Chaetomium, Talaromyces and Xylariaceae..$^{\mathbf{8 1 9}}$ The azaphilone derivatives could be defined as polyketides possessing a highly oxygenated pyranoquinone bicyclic core and a quaternary carbon center. ${ }^{8}$ In the present study, the new compounds 1 and 2 belong to the substructure type of sclerotiorin (3)-like azaphilones, which usually possess a $\gamma$-lactone, a conjugated ketone, a chlorine atom at $\mathrm{C}-5$, and a branched $\mathrm{C}_{7}$ side chain at C-3. ${ }^{8}$ Their differences compared with sclerotiorin (3) lay on the imparity of the side chains at C-3 and substituent groups at C-7. Compound 1 represents the second reported azaphilone with a $\mathrm{C} 4$ aliphatic side chain, ${ }^{20}$ a 3-buten-2-one moiety. Besides, compound 2 is a firstly reported azaphilone with a tetrahydrofuran ring at C-3.

The known compounds 3-6 belong to sclerotiorin structural skeleton with a branched $\mathrm{C}_{7}$ side chain. As reported in the literature, the absolute configurations of the side chains $[-\mathrm{CH}=$ $\left.\mathrm{CHCOH}\left(\mathrm{CH}_{3}\right) \mathrm{CH}(\mathrm{OH}) \mathrm{CH}\left(\mathrm{CH}_{3}\right) \mathrm{CH}_{2} \mathrm{CH}_{3}\right]$ in such azaphilones were determined by Mosher's method. ${ }^{\mathbf{1 6 , 1 8}}$ Fortunately, by slow crystallization from the mixture of EtOAc and hexane, single crystals of 6 suitable for X-ray diffraction were obtained. By detailed analysis of the crystal structure, the absolute configuration of $\mathbf{6}$ was established unambiguously as $7 R, 8 R, 8 \mathrm{a} R, 3^{\prime} R, 4^{\prime} R, 5^{\prime} S$ (Fig. 5) through refinement of Flack's parameter $0.07(3)$. It was the first time to confirm the absolute configuration of 6 by single-crystal X-ray diffraction.

Compounds 1-6 were evaluated for their antiviral activities against four viral strains, including herpes simplex virus (HSV), human enterovirus 71 (EV71), respiratory syncytial virus 1 (RSV1), and coxsackievirus B3 (CoxB3). Among them, compound 3 exhibited promising antiviral activities against HSV with an $\mathrm{IC}_{50}$ values of $19.5 \mu \mathrm{M}, 16$ folds more potent than the positive control ribavirin $\left(\mathrm{IC}_{50}=313 \mu \mathrm{M}\right)$ (Table 2 ). Besides, 
<smiles>CC[C@H](C)C(O)C(C)(O)/C=C/C1=CC2=C(Cl)C(=O)C(C)(O)[C@H](O)[C@H]2CO1</smiles>

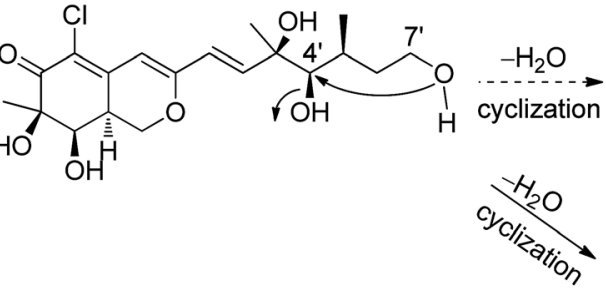<smiles>C[C@H]1CCO[C@@H]1C(C)(O)/C=C/C1=CC2=C(Cl)C(=O)C(C)(O)[C@H](O)[C@@H]2CO1</smiles>
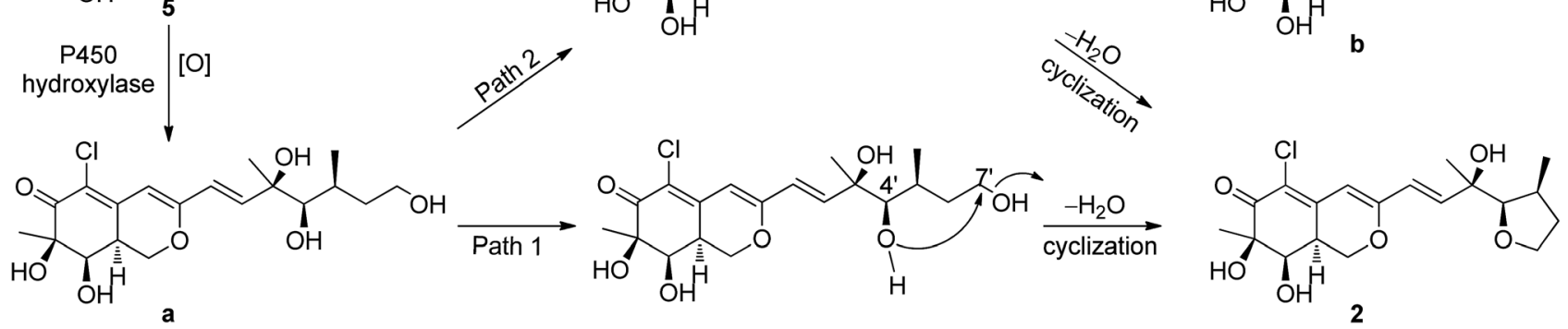

Scheme 1 Proposed biosynthetic pathway of 2 from 5 .

Table 2 Antiviral activities of 3 against HSV, EV71 and RSV1 cell lines

\begin{tabular}{lllll}
\hline Compd & Viral & $\mathrm{IC}_{50}(\mu \mathrm{M})$ & $\mathrm{TC}_{50}(\mu \mathrm{M})$ & $\mathrm{TC}_{50} / \mathrm{IC}_{50}$ \\
\hline 3 & $\mathbf{H S V}$ & 19.5 & 327 & 16.8 \\
3 & EV71 & 132 & 612 & 4.64 \\
3 & $\mathbf{R S V 1}$ & 108 & 327 & 3.02 \\
3 & CoxB3 & $\mathrm{NA}^{b}$ & $\mathrm{NA}^{b}$ & $\mathrm{NA}^{b}$ \\
Ribavirin $^{a}$ & $\mathbf{H S V}$ & 313 & $>10^{4}$ & $>32$ \\
Ribavirin $^{a}$ & $\mathbf{E V 7 1}$ & 418 & $>10^{4}$ & $>24$ \\
Ribavirin $^{a}$ & $\mathbf{R S V 1}$ & 78 & $>10^{4}$ & $>128$ \\
Ribavirin $^{a}$ & $\mathbf{C o x B 3}$ & 39 & $>10^{4}$ & $>256$ \\
${ }^{a}$ Positive control. $^{b}$ NA, not active. & &
\end{tabular}

3 also displayed antiviral activity against EV71 $\left(\mathrm{IC}_{50}=132 \mu \mathrm{M}\right)$, 3 times stronger than the positive control ribavirin $\left(\mathrm{IC}_{50}=\right.$ $418 \mu \mathrm{M})$. Comparison of their structures and antiviral activities revealed that the introduction of ester group in $\mathbf{3}$ may improve the antiviral activity.

Compounds 1-6 were also evaluated for their antibacterial activities towards six pathogenic bacteria. Only 3 showed moderate to weak antibacterial activities against Micrococcus lysodeikticus, Bacillus subtilis, Bacillus cereus, Micrococcus luteus, Bacillus megaterium, Shigella dysenteriae with the MIC values of $6.75,6.75,12.5,12.5,12.5$, and $12.5 \mu \mathrm{M}$, respectively (Table S2 $\dagger$ ). Compounds 3-6 were tested for their cytotoxic activities against four tumor cell lines. However, none of them showed any cytotoxicities.

\section{Experimental section}

\section{General experimental procedure}

Optical rotations were measured on a JASCO P-1020 digital polarimeter. UV spectra were recorded on a Beckman DU 640 spectrophotometer. ECD spectra were recorded on a Jasco J-815150S circular dichroism spectrometer. IR spectra were recorded on a Nicolet-Nexus-470 spectrometer using $\mathrm{KBr}$ pellets. NMR spectra were recorded on an Agilent DD2 $500 \mathrm{MHz}$ NMR spectrometer (500 MHz for ${ }^{1} \mathrm{H}$ and $125 \mathrm{MHz}$ for ${ }^{13} \mathrm{C}$ ), using TMS as an internal standard. The HRESIMS and ESIMS spectra were obtained from a Micromass Q-TOF spectrometer. The crystallographic data were collected on a Bruker SMART APEX-II CCD diffractometer equipped with graphite monochromatized Mo $\mathrm{K} \alpha$ radiation $(\lambda=0.71073 \AA)$. Semi-preparative HPLC was performed on a Hitachi L-2000 HPLC system coupled with a Hitachi L-2455 photodiode array detector. A Kromasil $\mathrm{C}_{18}$ semi-preparative HPLC column $(250 \times 10 \mathrm{~mm}, 5 \mu \mathrm{m})$ was used. Silica gel (Qing Dao Hai Yang Chemical Group Co.; 200-300 mesh), Sephadex LH-20 (Amersham Biosciences) and octadecylsilyl silica gel (Unicorn; 45-60 $\mu \mathrm{m}$ ) were used for column chromatography. Precoated silica gel $\mathrm{GF}_{254}$ plates (Yantai Zifu Chemical Group Co., Yantai, People's Republic of China) were used for analytical TLC.

\section{Fungal material}

The fungal strain P. sclerotiorum GDST-2013-0415 was isolated from the inner part of an unidentified sponge GDST-2013-04 collected from the coral reef at a depth of $10 \mathrm{~m}$ in the sea area of Shantou, Guangdong Province of China, in May 2013. The fungal identification was performed by analysis of its ITS region of the rDNA as described previously. ${ }^{21}$ The sequence data was submitted to the Genbank, with accession number MF467908. The strain was deposited in the Key Laboratory of Marine Drugs, the Ministry of Education of China, School of Medicine and Pharmacy, Ocean University of China, Qingdao, PR China.

\section{Extraction and isolation}

Fifty Erlenmeyer flasks of the fungal strain were cultivated in rice medium $(3.6 \mathrm{~g}$ of natural sea salt from Yangkou saltern, China; $70 \mathrm{~g}$ of rice; $100 \mathrm{~mL}$ of $\mathrm{H}_{2} \mathrm{O}$ ) for 40 days at room temperature. The fermented rice substrate was extracted repeatedly with EtOAc ( $400 \mathrm{~mL}$ for each flask), and the solvent was combined and concentrated in vacuo to afford a residue. The EtOAc residue (65 g) was subjected to silica gel CC using a step gradient elution with EtOAc-petroleum ether (0-100\%) and then with $\mathrm{MeOH}-\mathrm{EtOAc}(0-100 \%)$ to afford seven fractions (Fr.1-Fr.7). Fr.4 was first subjected to Sephadex LH-20 CC eluting with a mixture of $\mathrm{CHCl}_{3}-\mathrm{MeOH}(1: 1, \mathrm{v} / \mathrm{v})$ and then was further purified by using semi-preparative HPLC eluting with 
$50 \% \mathrm{MeOH}-\mathrm{H}_{2} \mathrm{O}\left(2 \mathrm{~mL} \mathrm{~min}^{-1}\right)$ to give compounds $3(27.0 \mathrm{mg})$ and 4 (4.1 mg). Fr.5 was separated on silica gel CC by using gradient elution of EtOAc-petroleum ether (0-100\%) and then further purified on an ODS column eluting with $25 \% \mathrm{CH}_{3} \mathrm{CN}-$ $\mathrm{H}_{2} \mathrm{O}$ to produce 1 (5.5 mg) and two subfractions, Fr.5-1 and Fr.5-2. Fr.5-1 was further purified by HPLC $\left(20 \% \mathrm{CH}_{3} \mathrm{CN}-\mathrm{H}_{2} \mathrm{O}\right)$ to afford $5(33.9 \mathrm{mg})$ and $6(18.2 \mathrm{mg})$. Fr.6 was isolated by silica gel CC eluting with $\mathrm{CHCl}_{3}-\mathrm{MeOH}(30: 1, \mathrm{v} / \mathrm{v})$, then was further purified by using semi-preparative HPLC eluting with $80 \%$ $\mathrm{MeOH}-\mathrm{H}_{2} \mathrm{O}$ to give compound $2(1.3 \mathrm{mg})$.

Peniciazaphilone D (1). Yellow gum; $[\alpha]_{\mathrm{D}}^{20}+52.7$ (c 0.16, $\mathrm{MeOH}) ; \mathrm{C}_{14} \mathrm{H}_{15} \mathrm{ClO}_{5} ; \mathrm{UV}(\mathrm{MeOH}) \lambda_{\max }(\log \varepsilon): 208$ (3.67), 338 (3.23) nm; IR (KBr) $\nu_{\max } 3633,2922,2362,1701,1540,1383$, $1187 \mathrm{~cm}^{-1} ;{ }^{1} \mathrm{H}$ NMR (acetone- $d_{6}, 500 \mathrm{MHz}$ ) and ${ }^{13} \mathrm{C} \mathrm{NMR}$ (acetone- $d_{6}, 125 \mathrm{MHz}$ ) see Table 1; ESIMS $m / z 299[\mathrm{M}+\mathrm{H}]^{+}$; HRESIMS $m / z$ 299.0675 $[\mathrm{M}+\mathrm{H}]^{+}$(calcd for $\mathrm{C}_{14} \mathrm{H}_{16} \mathrm{ClO}_{5}$, 299.0681).

Peniciazaphilone D (2). Yellow gum; $[\alpha]_{\mathrm{D}}^{20}+34.0(c \quad 0.05$, $\mathrm{MeOH}) ; \operatorname{UV}(\mathrm{MeOH}) \lambda_{\max }(\log \varepsilon): 206$ (3.53), 256 (3.06), 332 (2.88) nm; IR (KBr) $\nu_{\max } 3753,2928,2377,1703,1565,1371$, $1150 \mathrm{~cm}^{-1} ;{ }^{1} \mathrm{H}$ NMR (acetone- $d_{6}, 500 \mathrm{MHz}$ ) and ${ }^{13} \mathrm{C}$ NMR (acetone- $d_{6}, 125 \mathrm{MHz}$ ) see Table 1 ; ESIMS $m / z 385[\mathrm{M}+\mathrm{H}]^{+}$; HRESIMS $m / z$ 385.1412 $[\mathrm{M}+\mathrm{H}]^{+}$(calcd for $\mathrm{C}_{19} \mathrm{H}_{26} \mathrm{ClO}_{6}, 385.1412$ ).

X-ray crystallographic analysis of $1 . \mathrm{C}_{14} \mathrm{H}_{15} \mathrm{ClO}_{5} \cdot 1 / 2 \mathrm{H}_{2} \mathrm{O}$, $M_{\mathrm{r}}=307.72$, orthorhombic, space group $P 2{ }_{1} 2_{1} 2_{1}, a=7.7241$ (4) $\AA, b=16.3543$ (7) $\AA, c=22.3393$ (9) $\AA, \alpha=\beta=\gamma=90^{\circ}, V=2822.0$ (2) $\AA^{3}, Z=8, D_{\text {calcd }}=1.449 \mathrm{~g} \mathrm{~cm}^{-3}, T=170.0 \mathrm{~K}, \mu($ Mo K $\alpha)=$ $0.291 \mathrm{~mm}^{-1}, F(000)=1288$, crystal size $0.498 \times 0.201 \times$ $0.197 \mathrm{~mm}^{3}$, reflections collected 43557 , reflections unique 6467 $\left(R_{\text {int }}=0.0993, R_{\text {sigma }}=0.0566\right)$, final $R$ indices for $I>2 \sigma(I), R_{1}=$ $0.0495, \mathrm{w} R_{2}=0.1039, R$ indices for all data $R_{1}=0.0890, \mathrm{w} R_{2}=$ 0.1209 , Flack parameter $=-0.07(3)$. Crystallographic data for 1 have been deposited with the Cambridge Crystallographic Data Centre as supplementary publication number CCDC 1445327.

X-ray crystallographic analysis of $6 . \mathrm{C}_{19} \mathrm{H}_{27} \mathrm{ClO}_{6}, M_{\mathrm{r}}=386.85$, orthorhombic, space group $P 2{ }_{1} 2_{1} 2_{1}, a=12.446$ (3) $\AA, b=15.594$

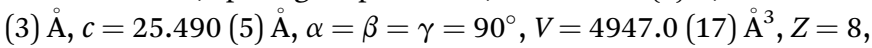
$D_{\text {calcd }}=1.039 \mathrm{~g} \mathrm{~cm}^{-3}, T=293(2) \mathrm{K}, \mu(\mathrm{Mo} \mathrm{K} \alpha)=0.179 \mathrm{~mm}^{-1}$, $F(000)=1648$, crystal size $0.3 \times 0.2 \times 0.2 \mathrm{~mm}^{3}$, reflections collected 74699 , reflections unique $11415\left(R_{\text {int }}=0.0849\right.$, $\left.R_{\text {sigma }}=0.0810\right)$, final $R$ indices for $I>2 \sigma(I), R_{1}=0.0566, \mathrm{w} R_{2}=$ $0.1465, R$ indices for all data $R_{1}=0.1298, \mathrm{w} R_{2}=0.1661$, Flack parameter $=0.07(3)$. Crystallographic data for 6 have been deposited with the Cambridge Crystallographic Data Centre as supplementary publication number CCDC 1445322.

\section{Antiviral activity assay}

The antiviral activities against HSV, EV71, RSV1 and CoxB3 were determined by the CPE inhibition assay according to established procedures. ${ }^{22}$ Ribavirin was used as a positive control.

\section{Antibacterial activity assay}

The antibacterial activity was evaluated by the conventional broth dilution assay. ${ }^{23}$ Six pathogenic bacterial strains, $M$. lysodeikticus, B. subtilis, B. cereus, M. luteus, B. megaterium, and
S. dysenteriae, were used, and ciprofloxacin was used as a positive control.

\section{Cytotoxicity assay}

The cytotoxicity against human erythroleukemia K562 cell lines was evaluated using MTT method. ${ }^{24}$ The cytotoxicity against human cervical carcinoma HeLa, human cancer of colon HCT116, and human lung carcinoma A549 cell lines were evaluated using SRB method. ${ }^{25}$ The four human cancer cell lines above were purchased from Shanghai Institute of Biochemistry and Cell Biology (SIBCB), Chinese Academy of Sciences (CAS). Adriamycin was used as a positive control.

\section{Conclusion}

In conclusion, two new azaphilones, penicilazaphilones $\mathrm{D}$ and E (1 and 2), along with four known analogs (3-6) were obtained from the sponge-derived fungus $P$. sclerotiorum. The absolute configurations of $\mathbf{1}$ and $\mathbf{2}$ were determined by single-crystal Xray diffraction analysis and comparison to the biosynthetically related known compound $\mathbf{5}$, respectively. It was the first time to confirm the absolute configurations of known compound, geumsanol G (6) by single-crystal X-ray diffraction. Compound 1 represents the second reported azaphilone with a C-4 aliphatic side chain, while compound 2 is the first reported azaphilone with a tetrahydrofuran ring at C-3 side chain. Compound 3 showed potent antiviral activity against HSV and EV71 with the $\mathrm{IC}_{50}$ values of 19.5 and $132 \mu \mathrm{M}$, respectively, more stronger than the positive control ribavirin.

\section{Conflicts of interest}

The authors declare that they have no conflict of interest.

\section{Acknowledgements}

This work was supported by the National Natural Science Foundation of China (No. U1606403; 81673350); the Fundamental Research Funds for the Central Universities (No. 201762017); the Open Research Fund Program of State Key Laboratory of Microbial Metabolism (Shanghai Jiao Tong University) (MMLKF1609), China; the Scientific and Technological Innovation Project Financially Supported by Qingdao National Laboratory for Marine Science and Technology (No. 2015ASKJ02); and the Taishan Scholars Program, China.

\section{Notes and references}

1 J. F. Imhoff, Mar. Drugs, 2016, 14, 19.

2 J. W. Blunt, B. R. Copp, R. A. Keyzers, M. H. G. Munro and M. R. Prinsep, Nat. Prod. Rep., 2012, 29, 144-222.

3 H. G. Ma, Q. Liu, G. L. Zhu, H. S. Liu and W. M. Zhu, J. Asian Nat. Prod. Res., 2016, 18, 92-115.

4 S. L. Zhou, M. Wang, H. G. Zhao, Y. H. Huang, Y. Y. Lin, G. H. Tan and S. L. Chen, Arch. Pharmacal Res., 2016, 39, 1621-1627. 
5 M. Chen, N. X. Shen, Z. Q. Chen, F. M. Zhang and Y. Chen, J. Nat. Prod., 2017, 80, 1081-1086.

6 F. Cao, J. K. Yang, Y. F. Liu, H. J. Zhu and C. Y. Wang, Nat. Prod. Rep., 2016, 30, 2448-2452.

7 D. N. Chen, S. S. Ma, L. He, P. B. Yuan, Z. G. She and Y. J. Lu, Tuberculosis, 2017, 103, 37-43.

8 J. M. Gao, S. X. Yang and J. C. Qin, Chem. Rev., 2013, 113, 4755-4811.

9 Y. F. Liu, R. Zhong, F. Cao, C. Wang and C. Y. Wang, Chem. Nat. Compd., 2016, 52, 548-551.

10 X. M. Hou, C. Y. Wang, Y. C. Gu and C. L. Shao, Nat. Prod. Res., 2016, 30, 2274-2277.

11 D. L. Zhao, C. L. Shao, Q. Zhang, K. L. Wang, F. F. Guan, T. Shi and C. Y. Wang, J. Nat. Prod., 2015, 78, 2310-2314.

12 J. Qi, C. L. Shao, M. Liu, X. Qi and C. Y. Wang, Chem. Nat. Compd., 2014, 50, 568-570.

13 J. Qi, C. L. Shao, Z. Y. Li, L. S. Gan, X. M. Fu, W. T. Bian, H. Y. Zhao and C. Y. Wang, J. Nat. Prod., 2013, 76, 571-579.

14 C. L. Shao, C. Y. Wang, Y. C. Gu, M. Y. Wei, J. H. Pan, D. S. Deng, Z. G. She and Y. C. Lin, Bioorg. Med. Chem. Lett., 2010, 20, 3284-3286.

15 L. Pairet, S. K. Wrigley, I. Chetland, E. E. Reynolds, M. A. Hayes, J. Holloway, A. M. Ainsworth, W. Katzer, X. M. Cheng, D. J. Hupe, P. Charlton and A. M. Doherty, J. Antibiot., 2010, 48, 913-923.
16 S. Son, S. K. Ko, J. W. Kim, J. K. Lee, M. Jang, I. J. Ryoo, G. J. Hwang, M. C. Kwon, K. S. Shin, Y. Futamura, Y. S. Hong, H. Oh, B. Y. Kim, M. Ueki, S. Takahashi, H. Osada, J. H. Jang and J. S. Ahn, Phytochemistry, 2016, 122, 154-164.

17 J. Yang, X. L. Qi, G. Shao, Y. H. Pei, X. S. Yao and S. Kitanaka, Chin. Chem. Lett., 1998, 9, 833-834.

18 Q. F. Guo, L. L. Dong, X. Y. Zang, Z. J. Gu, X. Y. He, L. D. Yao, L. P. Cao, J. Z. Qiu and X. Guan, Nat. Prod. Res., 2015, 29, 2000-2006.

19 N. Osmanova, W. Schultze and N. Ayoub, Phytochem. Rev., 2010, 9, 315-342.

20 J. Ren, S. S. Ding, A. Zhu, F. Cao and H. J. Zhu, J. Nat. Prod., 2017, 80, 2199-2203.

21 X. Y. Qin, K. L. Yang, J. Li, C. Y. Wang and C. L. Shao, Mar. Biotechnol., 2015, 17, 99-109.

22 A. Grassauer, R. Weinmuellner, C. Meier, A. Pretsch, E. Prieschl-Grassauer and H. Unger, Virol. J., 2008, 5, 107.

23 G. Appendino, S. Gibbons, A. Giana, A. Pagani, G. Grassi, M. Stavri, E. Smith and M. M. Rahman, J. Nat. Prod., 2008, 71, 1427-1430.

24 T. Mosmann, J. Immunol. Methods, 1983, 65, 55-63.

25 P. Skehan, R. Storeng, D. Scudiero, A. Monks, J. McMahon, D. Vistica, J. T. Warren, H. Bokesch, S. Kenney and M. R. Boyd, J. Natl. Cancer Inst., 1990, 82, 1107-1112. 